\title{
NEOBVYKLÉ DEPOZITUM CÍRKEVNÍ PROVENIENCE Z HRADU ZÍTKOV U CHOCNĚ
}

\author{
MARTIN ČECHURA - DAVID VÍCH
}

Abstrakt: V roce 2013 bylo s pomoci detektoru kovů objeveno v areálu jádra hradu Zítkov (k. ú. Choceñ, Pardubický kraj, Česká republika) torzo rozstř́haného kalicha ukryté v keramické nádobè. Podle nálezu samého, nálezových okolností a s ohledem na výpověd' písemných pramenů se jedná o doklad kriminálního činu ze staršiho novověku, a to krádeže provedené v některém z kostelü. Po krádeži byl kalich rozstř́hán a část lupu skončila ukryta v nádobě v areálu opuštěného hradu.

Klíčová slova: kalich - starší novověk - kráděz - depot.

\section{An unusual find of religious provenance from the Zitkov castle, near Chocen̆}

Abstract: In 2013, metal detecting in the core of the Zitkov castle (Chocen cadastral zone, Pardubice Region, Czech Republic) revealed a fragment of a cut-up chalice hidden in a ceramic vessel. Judging by the find, the context and information from written sources, it evidences a criminal act taking place in the early modern age, a theft from one of the churches. The stolen chalice was subsequently cut into pieces and part of the loot ended up in the vessel hidden in the deserted castle.

Key words: chalice - early modern age - theft-hoard.

Při západním okraji Chocně se na zalesněném hřbetu nad řekou Tichou Orlicí nachází místo, kde stál hrad, nazývaný dnes podle někdejších majitelů pozemků Zítkov (obr. 1).

Poznávání vrcholně stř̌edověkých fortifikací $\mathrm{v}$ okolí Chocně patří $\mathrm{k}$ mimořádně obtížným úkolům. Př́ičinou je nesoulad mezi výpovědí pramenů a dochovanými hmotnými

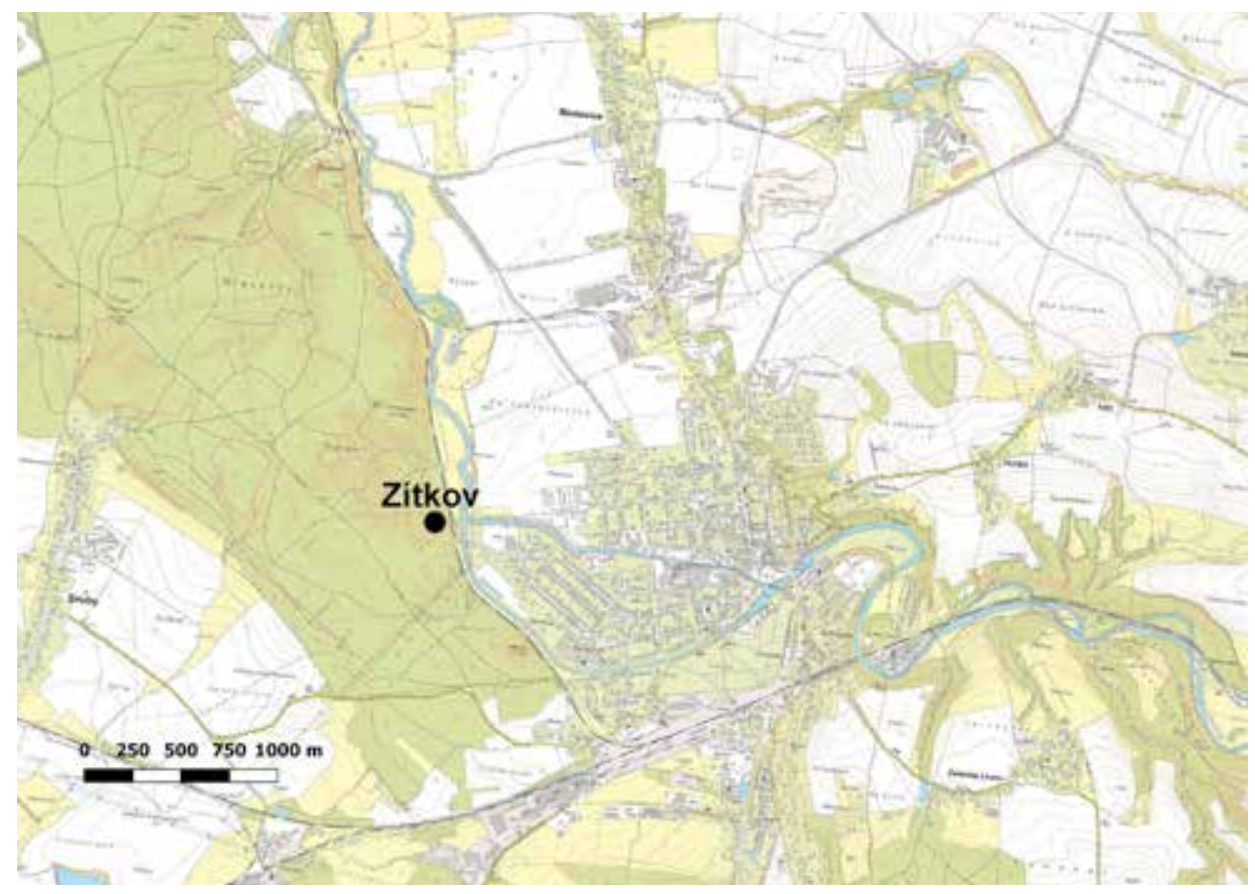

Obr. 1. Poloha hradu Zítkov.

Abb. 1. Lage von Burg Zítkov. 
pozůstatky - nedokážeme ztotožnit informace z pramenů písemných s relikty dochovanými do dnešních dnů. Zlepšit to dnes již mohou jedině nové poznatky získané k jednotlivým lokalitám archeologickým zpo̊sobem.

V souvislosti s hradem Zítkov jsou důležité zprávy z průběhu 14. století o rozdělení Chocně, kdy jedna polovina připadla Lichtemburkům, kteří vlastnili panství litické, druhou polovinu měli pánové z Potštejna držící hrad Žampach. Zatímco v souvislosti s žampaškou částí Chocně se žádný hrad ani tvrz nepřipomíná, Ješek Pykna z Lichtemburka se k roku 1388 uvádí jako pán na Novém hradě a za Zikmunda Pikny z Lichtemburka se na počátku 15. století v Chocni připomíná tvrz. V roce 1433 došlo $\mathrm{v}$ rámci sporů o dědictví po bezdětném Zikmundovi Pyknovi z Lichtemburku k vyplenění Chocně Janem Koldou ze Žampachu, Mikulášem Trčkou z Lípy a dalšími (Sedláček 1883, 249-251; Musil 1995, 36).

Se zprávami o Novém hradě je obvykle spojován právě Zítkov, což vedle dvoupalácové dispozice hradu potvrzují i z větší části dosud nepublikované archeologické nálezy získané zevrubným detektorovým průzkumem datované do pokročilého 14. až do staršího úseku 15. století. Detektorový průzkum zároveň doložil dobývání hradu (Vích 2017). Při detektorové prospekci jsme se věnovali svahům, předhradí a bezprostřednímu okolí hradu, stranou pozornosti jsme ponechali plochu hradního jádra se dvěma depresemi interpretovanými jako suterény věžových staveb. Vzhledem k hojnému výskytu keramiky a mazanice se zde dá počítat se složitějšími intaktními situacemi a my jsme v době detektorového průzkumu nedokázali zajistit geodetické zaměření případných mikrovrypů se složitějšími stratigrafiemi.

Na jaře 2014 byla archeologovi Regionálního muzea ve Vysokém Mýtě ukázána poškozená keramická nádoba nalezená při detektorovém průzkumu údajně v širším okolí hradu datovatelná do staršího novověku. Při dotazu, na jaký kov detektor reagoval (takovéto nádoby tvoří nezrrídka obal mincovních depotů), bylo sděleno, že nádoba obsahovala rozstříhaná zavařovací vička, která měl nálezce naštěstí stále u sebe. Po jejich prezentaci archeologovi bylo okamžitě jasné, že skutečně nejde o recentní odpad, ale o archeologicky mimořádně zajímavý nález. Zjevně se jednalo o zbytky rozstř́haného kalicha vyrobeného ze stříbra se zřetelným zlacením, které bylo patrné na některých zlomcích, přičemž mimo amorfních ústřižků plechu tvořících valnou část souboru bylo možné identifikovat části nohy a rozstříhaný ořech (nodus). Ohledání místa nálezu dne 28. dubna 2014 navíc k údivu nálezce i archeologa ukázalo, že k objevu nedošlo v okolí hradu, ale přímo ve svahu uvnitř deprese interpretované obvykle jako suterén severní palácové stavby. Místo nálezu udávají souřadnice (WGS 84, UTM) E 0586011, N 5539461 (obr. 2). Dle informací poskytnutých nálezcem a ověření situace na místě nálezu ležel soubor v hloubce asi $30 \mathrm{~cm}$ pod kořeny buku ve světle šedohnědé písčité půdě kryté tmavou lesní humusovou vrstvou. Nález, k jehož objevu došlo někdy na jaře roku 2013, byl okamžitě po zjištění jeho významu nálezcem předán do sbírek Regionálního muzea ve Vysokém Mýtě (podsbírka archeologie, inv. č. 7551-7552).

\section{Popis nálezů}

Nalezený hrnek s páskovým uchem o průměru ústí $82 \mathrm{~mm}$ a výšce $93 \mathrm{~mm}$ je vně na podhrdlí opatřen dvojicí oběžných rýh, je cihlově červený s hlazeným neglazovaným povrchem, uvnitř se žlutohnědou polevou, okraj je zhruba z jedné třetiny olámán (obr. 3). Rozstříhané torzo (do té míry, že není možná ani kresebná rekonstrukce) stř́ibrného kalicha má celkovou hmotnost $248,8 \mathrm{~g}$ (po vyčištění), počet fragmentů činí 137 ks (přičemž jedna část je tvořena několika kusy kovu spojeného korozními produkty, takže celkový počet ústřižků se pohybuje okolo $150 \mathrm{ks}$ ), rozstř́ihaný nodus je na povrchu zlacený (obr. 4-6).

Kalich představuje nejdůležitější součást liturgického mobiliáře potřebného pro sloužení mše (souhrnně k vývoji kalicha Braun 1932, 17-196). Symbolizuje svátost eucharistie odvozené z poslední večeře Ježíše Krista a jeho apoštolů. V kalichu se odehrává jedno z největších mystérií křest’anské bohoslužby - proměna vína v krev Kristovu. Přirozeným doplňkem kalicha je paténa - obětní miska pro uložení hostie určené k proměnění v tělo Páně. Kalichy měly být vyráběny 


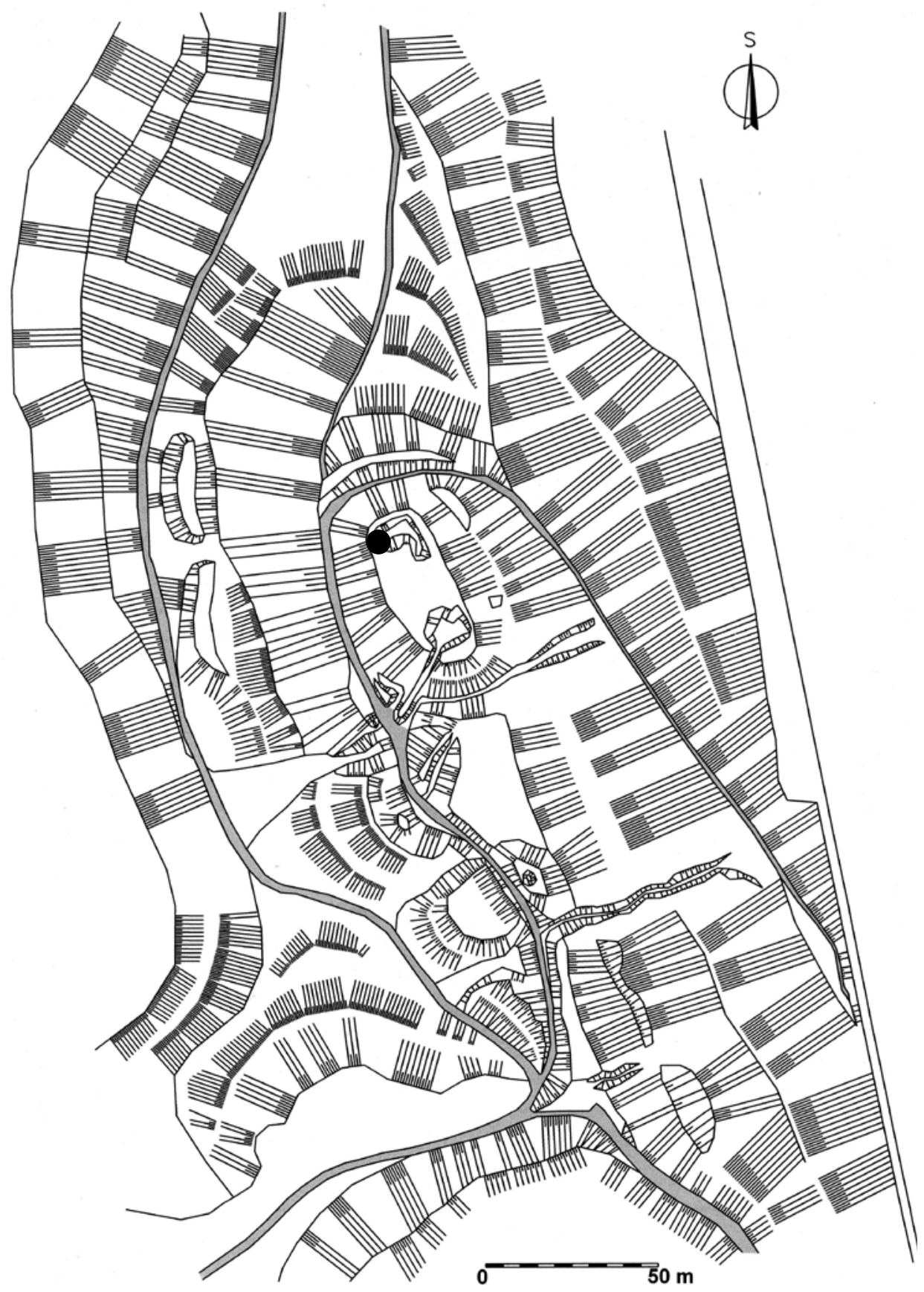

Obr. 2. Geodetický plán hradu s vyznačeným místem nálezu. Zdroj Zeměměřičská kancelář Kostelec nad Orlicí.

Abb. 2. Geodätische Planskizze der Burg (erstellt vom Vermessungsbüro Kostelec nad Orlicí) mit eingezeichnetem Fundort. 


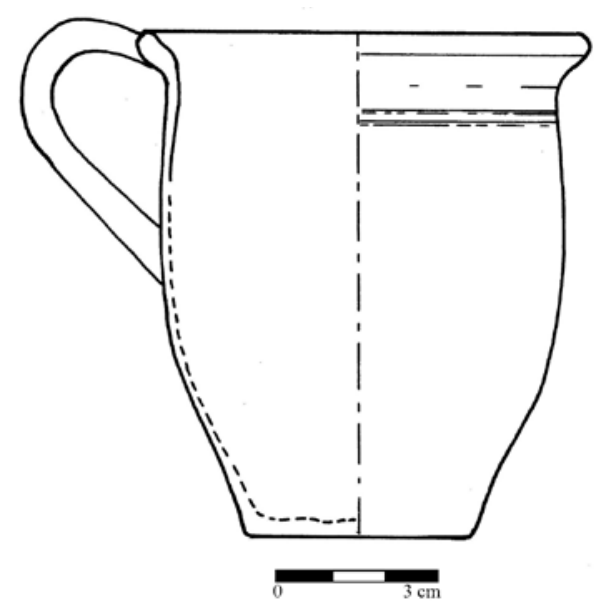

Obr. 3. Nádobka, v níž byl soubor uschován. Kresba D. Vích.

Abb. 3. Gefäß, in dem der Komplex aufbewahrt wurde. Zeichnung D. Vích.

z drahých kovů, ze zlata, případně ze stříbra. V krajním př́ípadě mohl být zhotoven i z běžného kovu, tehdy však měl být alespoň pozlacen. Výslovně bylo zakázáno používat kalichy skleněné, u kterých hrozilo rozbití a znesvěcení proměněného vína, a také kalichy měděné, ve kterých docházelo k oxidaci kovu, což mohlo vyvolávat nutkání ke zvracení.

Nejstarší raně středověké kalichy měly vejčitou kupu nasazenou přímo na masivní kuželovitou nohu, někdy oddělenou nevýrazným nodem (Elbern 1964, 3-12). V průběhu vrcholného středověku se tvar kalicha ustálil na podobě, která je - až na detaily - používána do současnosti. Základem je vlastní pohár (kupa), většinou vejčitého, parabolického či kuželového tvaru, a noha (pes), původně kruhová, od 15. století nejčastěji šestilistá. Kupa a pes jsou spojeny dř́ikem (stipes), který je uprostřed či v horní části přerušen ořechem (nodus).

Symbolický i reprezentativní význam kalicha se odrážel v jeho výzdobě. Zatímco jednoduché kalichy určené k běžnému provozu, zejména ve venkovském prostředí, mohou být opatřeny jen jednoduchým, rytým či tepaným ornamentem, případně jsou zcela bez výzdoby, náročnější exempláře rozehrávají širokou škálu uměleckého projevu. Výzdoba se soustřed’uje především na nohu a dřík, které poskytují prostor pro rytou, tepanou, plastickou či emailovou výzdobu, a to jak ornamentální, tak se symbolickým ikonografickým programem. Od 15. století nabývá na významu i koš, podepírající spodní část poháru. Naopak vlastní kupa zůstává převážně hladká, pouze s profilovaným či jemně zdobeným horním okrajem (Zápalková 2017). Monumentální zdobnosti dosahují kalichy v období baroka. Abstraktní, spíše plošný manýristický dekor je v poslední třetině 17. století nahrazován naturalistickou výzdobou, často prováděnou ve vysokém reliéfu, pokrývající většinu plochy předmětu. Tento trend vrcholí v průběhu 18. století nástupem rokajového ornamentu, se kterým se pojí i rozvolnění do té doby stále udržovaného tvaru a symetrických proporcí. Až na sklonku 18. století můžeme zaznamenat postupný návrat k jisté stř́izlivosti (Urešová 2001; Zápalková 2010).

Zlomky nalezené na Zítkově se vyznačují velmi prostou morfologií a absencí složitější výzdoby. Z kalicha se dochovala pouze část zřejmě prosté nohy kruhového tvaru, zdobené na okraji jednoduchým perličkovým dekorem, a část dř́ku s nodem. Ten je jednoduše vytepán a zdoben prostým vybíjeným perličkovým ornamentem. Nepochybně se jednalo o kalich sloužící k běžnému uživání při bohoslužbách. Nevýraznost dochovaných zlomků neumožňuje jednoznačnou dataci, vzhledem k podobě nohy a tvaru nodu jej však můžeme rámcově zařadit do období pozdního středověku až časného novověku (15.-16. století). Oproti tomu nádobka svým provedením odpovídá keramické produkci z pokročilého 16. století až průběhu 17. století, dokládají to nádoby datované nálezy mincí ze Slavkova (Nekuda 1980, 424), Slaného či se Zítkovem 

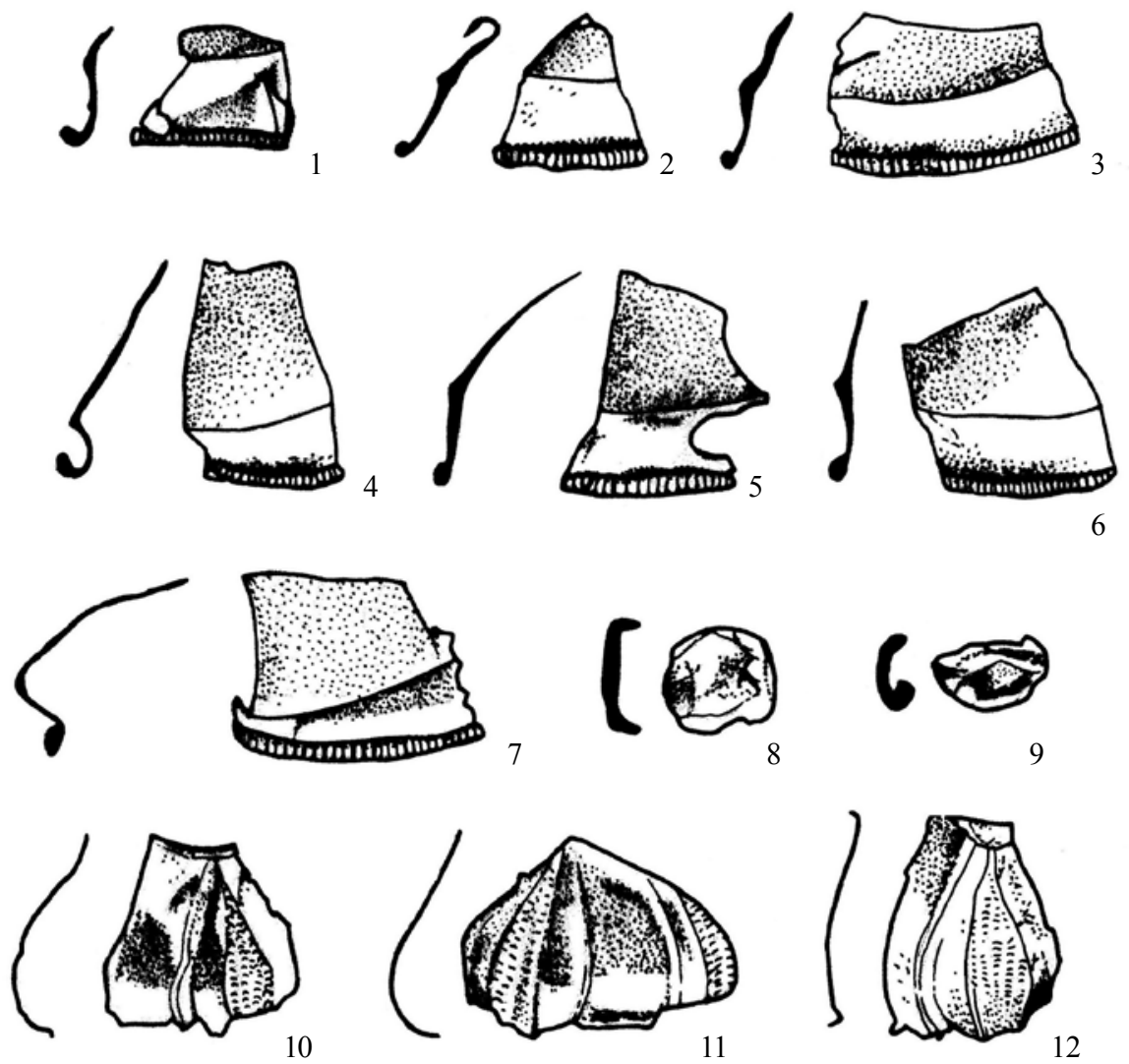

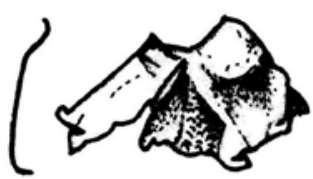

13
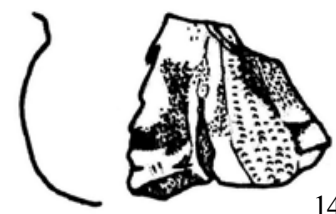

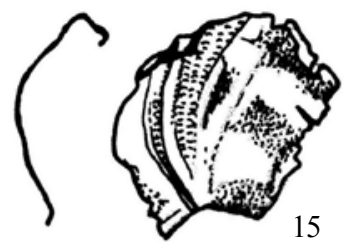

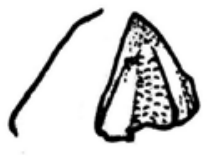

16

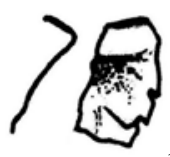

17

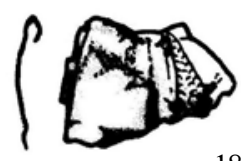

18

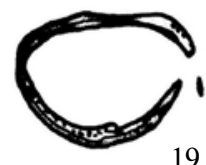

19

Obr. 4. Morfologicky určitelné zlomky z nálezu. Kresba K. Urbanová.

Abb. 4. Morphologisch bestimmbare Bruchstücke des Fundes. Zeichnung K. Urbanová. 

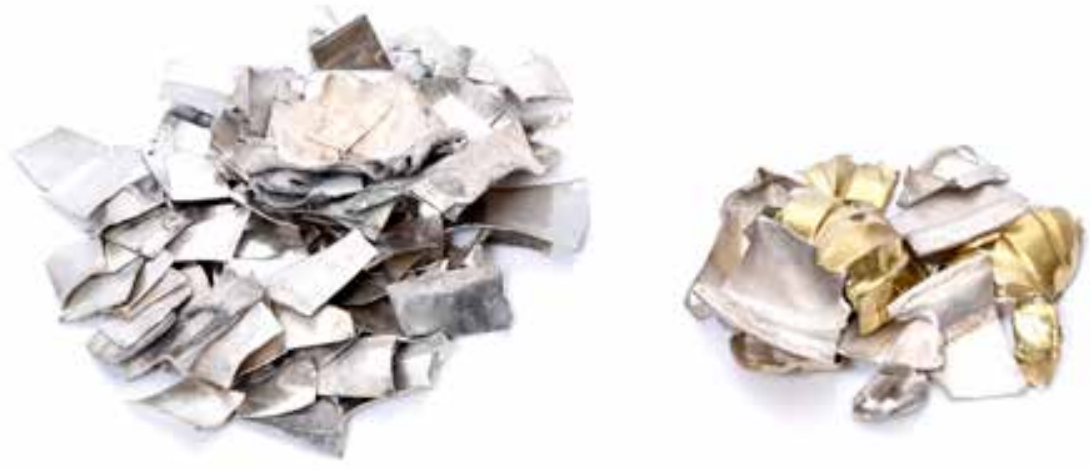

Obr. 5. Celkové foto nálezu. Foto M. Štěpán. Abb. 5. Gesamtbild des Fundes. Foto M. Štěpán.

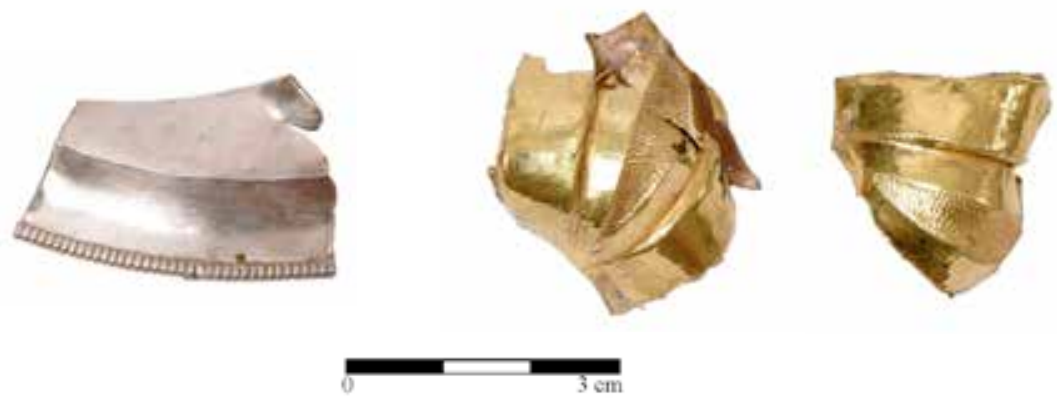

Obr. 6. Foto vybraných morfologicky výraznějších zlomků. Foto M. Štěpán.

Abb. 6. Ausgewählte morphologisch ausgeprägtere Bruchstücke. Foto M. Štěpán.

bezprostředně sousedícího Dobříkova (Radoměrský-Richter 1974, 154-156). Určitá časová disproporce mezi datací torza kalicha a keramické nádoby, v níž bylo torzo uložené, je celkem logická, když uvážíme, že zatímco kalich byl jako drahocenný liturgický předmět nepochybně používán a uchováván po delší dobu, pro uschování drahého kovu rozstř́íhané liturgické nádoby byla využita aktuálně dostupná, a tudíž běžně používaná keramická nádoba.

$\mathrm{S}$ nálezy liturgických potřeb se $\mathrm{v}$ archeologických pramenech setkáváme spíše zř́dka. Specifickou situací jsou nálezy kalichů v pohřebním kontextu. Pomineme-li spíše výjimečné př́ípady z raného středověku, jako je např́íklad známý kalich nalezený v Kolíně (Košta-Lutovský 2014), setkáváme se s kalichy v hrobech kněží a vyšších duchovních hodnostářů. Z českého prostředí jsou známé trři exempláře pohřebních kalichů a patén z 12., respektive 13. století nalezené v areálu Pražského hradu (Frolík 1988; 2005; Frolík-Siglová 2005). Poněkud četnější jsou nálezy v Polsku, např́klad na krakovském Wawelu, v Týnci, v Gnizně i jinde (Firlet-Zaitz 2006; Dąbrowska 2008a; 2008b), a především v západní Evropě (Sanke 2012). Kalichy, případně jejich dřevěné a voskové napodobeniny, se v hrobech duchovních objevují hluboko do novověku, často ve spojení s keramickými nádobami (Unger 1997; Thier 1999). Vzhledem k okolnostem nálezu však není třeba naši pozornost dále tímto směrem rozvíjet.

V sídelních kontextech jsou archeologické nálezy liturgických předmětů poměrně vzácné. Ojedinělým př́ikladem z českého prostředí je nález gotického ciboria, ke kterému došlo v roce 2004 na Novém Městě pražském v ulici Na Porríčí. K uložení předmětu došlo pravděpodobně v průběhu první poloviny 15 . století. Historické okolnosti naznačují, že k deponování ciboria 
mohlo dojít $\mathrm{v}$ souvislosti s několika vlnami obrazoboreckých bouří, při kterých docházelo k drancování a plenění kostelů (Royt-Žegklitz 2009).

Přestože archeologické výzkumy nám v tomto směru neposkytují dostatečnou oporu, mohou příčinu neobvyklého depozitu naznačit prameny písemné, a to především dochované trestní (výslechové) protokoly hovořící o příčinách a průbězích krádeží v městských i venkovských kostelích. $V$ případě nálezu ze Zítkova je přitom interpretačně zcela zásadní skutečnost, že původce depotu zjevně nezajímal kalich jako předmět, ale pouze jako drahý kov. Tuto skutečnost zřetelně dokládá rozstř́íhání předmětu na malé části.

Krádeže kostelního vybavení se v písemných pramenech objevují relativně zřídka. Důvody jsou především dva. První, byt' ne vždy rozhodující, mohla být (vedle toho, že takový čin přímo zasahoval do sakrální sféry a již tím řadu případných pachatelů odrazoval) obava z př́ísnějších trestů - krádež v kostele mohla být posuzována jako svatokrádež, za kterou podle Koldína hrozilo provinilci oběšení (Jireček 1876,39). Podobně př́ísné tresty předpokládal zákoník Constitutio criminalis Josephina. V př́ípadě krádeže monstrancí a kalichů s božím tělem bylo na místě upálení, při krádeži bohoslužebných předmětů bez svátostí pak u žen stětí a u mužů oběšení s následným upálením (Josefina 1708,91). Ve skutečnosti bývaly vynášené tresty často méně prrísné, a to bud's ohledem na věk nebo sociální postavení obviněného, nebo proto, že přestupek byl posuzován jako běžná krádež, případně byly shledávány i další polehčující okolnosti (Francek 2012, 94; Dibelka-Šimánek 2017, 39-42).

Závažnější problém spočíval $\mathrm{v}$ tom, že odcizené bohoslužebné předměty byly jen velmi obtížně prodejné. Nejčastější variantou tak byl prodej židovským překupníkům, a to bud' vcelku, nebo - a to mnohem častěji - po jejich zničení, jako pouhá surovina z drahého kovu: „Co sem dobrovolně vyznal, na tom že umřit chci. A ty kalichy v lesích za Poběžovicemi jest ten Vávra sekerou stloukl. A ten je Vávra u sebe má, než o penize na hromádky dělili sme se, co jich bylo, dostalo se mi jich okolo 20 kop grošủ čes. A s tím Vávrou sem se seznámil u Livy, šenkýre na hradě v Litomyšli; ten Vávra v tom prvý bejval, že kostely loupal, a pravil, že on to ví, kam nýsti ty kalichy“ (Francek 2016, 240).

Pro krádeže v kostelích je možné vysledovat několik charakteristických rysů. Jen výjimečně se jich dopouštěli jednotlivci, typické jsou spíše větší organizované skupiny či přinejmenším dvojice. Zásadní při tom byla znalost schopného a ochotného překupníka: „Též jsme kostel vyloupali s Vávrou Starejm a Janem Černohorským na Moravě od Žd'ára (...). Též sme vzali z toho kostela tři kalichy, i taky což sme z Janovic vzali a ty jest Vávra Starej stlouk a zač jest těch kalichů prodal, z toho jest mi dil ve vsi za Podolí, jenž slove Bedřichovici, Janovi, židu v Slavkově po levé straně bydlicimu, douc od Brna, druhej dům od brány a já sem před tím domem stál a ten Jan žid jest tu s otcem tu v Slavkově, jest ten žid sám mladej velkej pacholek a votce má starýho, než já sem ho neviděl, než co mi Vávra Starej o něm správu dal“" (Francek 2016, 241).

„Též jsem pomáhal kostela v městě Jaroměř s Petrem Horákovým z Jaroměre a s Vávrou Starým a Janem Černohorským vyloupati. A což tam kalichů sme vzali, ty jest Vávra Starej v Slavkově Janovi židu po 5 kopách míš. prodával“ (Francek 2016, 241).

V roce 1563 byl vyslýchán Jan Vondráček z Náměště, který se s jistým Šplíchalem a Kolesou a Jiř́ím Skoumalem vloupali do kostela v Náměšti. Jan Vondráček stál na stráži a jeho společníci zatím z truhly v kostele ukradli jeden zlatý a dva pozlacené kalichy a jeden ubrus. Kalichy pak Skoumal prodal lednickému židu za 130 zlatých (Francek 2002, 137-138). Vítek Černý z Jívového v roce 1591 přiznal se svými společníky vloupání nejméně do tř́i kostelů. Bohoslužebné předměty (kalichy, monstrance, misky, lžičky, ubrusy) opět prodali židům (Tomášková 2014, 32). Bohoslužebné předměty představovaly „horké zboži“ a jako takové nebylo žádoucí je přechovávat u sebe, ale bylo třeba nalézt vhodný úkryt. Václav Večeřa z Vícenic ukryl ukradený kalich v korytě v maštali (Tomášková 2014, 32). Vít, syn zemřelého Marka ze Zminného, uvedl v roce 1560 před pardubickým soudem: „Ve vsi Kolesách vyloupali jsme okno do kaply a vzali jsme dva kalichy, nevím byly-[1i] sou stř́brné. A vložili sme je do vrby na rychtárově zahradě. A odtud sme je vystavili na rychtářrovo pastviště. I vzali je zase" (Francek 2016, 190). 
Václav z Dačic se vyznal v roce 1567 takto: „Míli za Horou vzali sme 16 tolarů v nějaký věži u kostela (...). Těch kalichů sem já nevzal, (...) u Chrudimě a ty kalichy sme zakopali u vsi Škrovádu (...)“(Francek 2016, 224-225).

Opuštěná, a přesto dobře poznatelná místa mimo běžné osídlení tak představovala ideální skrýše pro dočasnou úschovu kořisti do té doby, než bylo možné ji bezpečně dopravit k překupníkovi.

Ve skutečnosti krádeže bohoslužebného vybavení tvoří ve sledovaných případech jen menší část. Hlavním cílem vykradačů kostelů byly především hotové peníze. Jednalo se jak o drobné ofěry v pokladničkách, tak i o zádušní peníze, uschované v truhle v sakristii (Stuchlá 2004, 162). Peněz bývalo v kostele značné množství; tak např́íklad v květnu 1604 vyznal před soudem města Poličky zloděj Portl, že v kostele v Újezdě uloupil asi 150 kop míšeňských grošů a dva kalichy, které prodal židu v Litomyšli za 50 kop. Mimo to vyloupil ještě další dva kostely (Francek $2011,122)$. Pozornost vzbuzovaly také stříbrné, vzácně i zlaté votivní dary přinášené poutníky k zázračným sochám a obrazům. V roce 1717 bylo například z malé kaple ve Skočicích ukradeno na 20 stříbrných obětin v hodnotě asi 220 zl. (Stuchlá 2004, 173). Kašpar Glaser ze Stř́ižova si v roce 1670 odnesl z kostela ve Štěpánovicích 2 zlaté, z kostela v Ledenicích 10 zlatých a ze Štěpánovic dokonce 53 zlatých (Dibelka-Šimánek 2017, 37).

Specifika loupeží na posvěcené půdě nutně vedla $\mathrm{k}$ jisté specializaci takto zaměřených zlodějů. Jen zřídka se setkáváme s tím, že by se kostel stal jen jedním z náhodných cílů krádeže. Naopak, ve většině výslechů se objevuje větší množství vykradených svatyní. Pozoruhodný je v tomto ohledu dobře zdokumentovaný př́ípad Johany Peřkové, narozené ve vsi Suchdol na Třeboňském panství. Její životní i kriminální osudy byly několikrát podrobně zpracovány (naposled Čechura 2015). V našem tématu nás zaujme životní epizoda, ke které došlo v roce 1743, rok po jejím seznámení s Josefem Kaňkou. Po neúspěšném pokusu o „běžné“ krádeže se soustředili na vykrádání kostelů. Podařilo se zdokumentovat pět krádeží ve čtyřech kostelích i výši způsobené škody: Soběslav, kostel sv. Marka (18 zl. 6 kr.), Hartvíkov, kostel sv. Petra a Pavla (12 zl. 5 kr.), Dražice, kostel sv. Jana Křtitele (4 zl. 15 kr.) a Tábor, kostel sv. Jakuba (2 krádeže, celkem 11 zl. 13 kr.). Zajímavé je, že oba zloděje nezajímaly liturgické předměty, s jejichž prodejem si neuměli poradit, ale spíše textilie. Ty dvojice prodávala v okolních vesnicích, některé sama Peřková použila k přešití oděvů (Čechura 2008, 84-85; 2015, 165-171). Podobně v roce 1700 kradla Alžběta Rybová v kostele sv. Petra a Pavla v Soběslavi textilie, ze kterých šila košile a další součásti oděvu (Čechura 2008, 96). Na Prachaticku rrádila v roce 1700 organizovaná skupina, která kromě další trestné činnosti také vykrádala kostely (Stuchlá 2004, 173). Podrobněji bylo zpracováno loupení Václava Kalivody, kterému byly prokázány krádeže v Jesenici, Počepicích, Křečovicích, Višňové a Slapech (Ryantová 1999).

Spíše náhodné sondy do archivních pramenů a nálezové okolnosti ukazují, že právě v krádeži kostelního mobiliáře můžeme nalézt nejpravděpodobnější příčinu uložení části kalicha na hradě Zítkově. Kalich byl odcizen z blíže neznámého kostela a z obavy před jeho nalezením a identifikací byl rozstříhán na malé kousky, určené k prodeji překupníkovi a následnému roztavení. Hrad, v té době již bezpečně opuštěný, představoval ideální úkryt pro uschování kořisti; zřícenina nepochybně nabízela celou řadu orientačních bodů usnadňujících pozdější nalezení a vyzvednutí kořisti. Vezmeme-li v úvahu množství a hmotnost nalezených zlomků, pak můžeme předpokládat, že máme k dispozici přibližně polovinu, spíše však třetinu původního kalicha. Zcela nám například v dochovaných odstř̌žcích chybí jakákoliv část kupy. Tato skutečnost naznačuje i počet původních pachatelů. Za jakých okolností došlo $\mathrm{k}$ úkrytu příslušného podílu a proč si jej jeho nový majitel už nikdy nevyzvedl, však již musíme ponechat na fantazii čtenáře. 


\section{Literatura}

BRAUN, J., 1932: Das christliche Altargerät in seinem Sein und in seiner Entwicklung. Heidelberg. ČECHURA, J., 2008: Kriminalita a každodennost v raném novověku. Jižní Čechy 1650-1770. Praha. - 2015: Neklidný život obyčejné ženy. Johana Peřková (1703-1745). Praha.

DĄBROWSKA, E., 2008: Średniowieczny ceremoniał pogrzebowy wyższego duchowieństwa polskiego. Studium archeologiczno-historyczne. In: Dąbrowska, E., Groby, relikwie i insygnia. Studia z dziejów mentalności średniowiecznej, 13-38. Warszawa.

- 2008a: Średniowieczne pochówki biskupie w katedrze krakowskiej. Stan badań. In: Dąbrowska, E., Groby, relikwie i insygnia. Studia z dziejów mentalności średniowiecznej, 39-56. Warszawa.

DIBELKA, J.-ŠIMÁNEK, J., 2017: Krádeže v jihočeských kostelích na sklonku 17. a v první polovině 18. století, Opera historica 18, 26-44.

ELBERN, V. H., 1964: Der eucharistische Kelch im frühen Mittelalter. Berlin.

FIRLET, E.-ZAITZ, E., edd., 2006: Kraków w chrześcijańskiej Europie X-XIII w. Kraków.

FRANCEK, J., 2002: Dějiny loupežnictva. Zloději, loupežníci, lupiči, pytláci a žháři v českých dějinách. Praha.

- 2011: Velké dějiny zemí Koruny české. Tematická řada 3: Zločinnost a bezpráví. Praha.

- 2012: Zločin a trest na Jičínsku v 16.-18. století. Jičín.

-2016: Pardubické smolné knihy 1538-1626. Pardubice.

FROLÍK, J., 1988: Druhý archeologický nález kalicha z Pražského hradu, Sborník Kruhu přátel Muzea hl. města Prahy $1,95-102$.

- 2005: Hroby významných duchovních vně baziliky sv. Víta. In: Pohřbívání na Pražském hradě a jeho předpolích I.1. Castrum Pragense 7 (Tomková, K., ed.), 141-144. Praha.

FROLÍK, J.-SIGLOVÁ, V., 2005: Poznámky ke konzervování církevního náčiní z hrobů na Pražském hradě. In: Castrum Pragense 6 (Maříková-Kubková, Jana, ed.), 75-88. Praha.

JIREČEK, J., ed., 1876: Práva městská království českého a markrabství Moravského spolu s krátkou jich summou od M. Pavla Krystyána z Koldína. Praha.

JOSEFINA 1708: Nové právo útrpné a hrdelní pro království České, markrabství Moravské a knížectví Slezské. Praha.

KOŠTA, J.-LUTOVSKÝ, M., 2014: Raně středověký knížecí hrob z Kolína. Praha.

MUSIL, F., 1995: Hrady, tvrze a zámky okresu Ústí na Orlicí. Ústí nad Orlicí.

NEKUDA, V., 1980: Korpus středověké keramiky datované mincemi z Moravy a Slezska - Das Korpus der mittelalterlichen münzdatierten Keramik aus Mähren und Schlesien, AH 5, 389-450.

RADOMĚRSKÝ, P.-RICHTER, M., 1974: Korpus české středověké keramiky datované mincemi, SbNM A XXVIII, 57-168.

ROYT, J.-ŽEGKLITZ, J., 2009: O krádeži a nálezu gotického ciboria na Novém Městě pražském The theft and discovery of a Gothic ciborium in Prague‘s New Town, AR LXI, 684-696.

RYANTOVÁ, M., 1999: Krádeže v kostelích vltavského a podbrdského kraje za třicetileté války, Z pomocných věd historických 14 - Acta universitatis carolinae philosophica et historica 5, 221-229.

SANKE, M., 2012: Die Gräber geistlicher Eliten Europas von der Spätantike bis zur Neuzeit: Archäologische Studien zur materiellen Reflexion von Jenseitsvorstellungen und ihrem Wandel. Bonn.

SEDLÁČEK, A., 1883: Hrady, zámky a tvrze království českého II. Hradecko. Praha.

STUCHLÁ, P., 2004: Prachatický vikariát 1676-1750. Vybrané otázky církevní správy. Praha.

THIER, B., 1999: Die Schüssel im Grab: Eine archäologisch-volkskundliche Betrachtung zu keramischen Grabbeigaben im christianisierten Mitteleuropa. In: Archäologie als Sozialgeschichte. Studien zu Siedlung, Wirtschaft und Gesellschaft im frühgeschichtlichen Mitteleuropa. Festschrift für Heiko Steuer zum 60. Geburtstag (Brather, S.-Bucker, C.-Hoeper, M., edd.), 139-149. Rahden.

TOMÁŠKOVÁ, L., 2014: Hrdelní kriminalita na Velkobítešsku v letech 1556-1636. Bakalářská práce, Historický ústav FF MU.

UNGER, J., 1997: Hroby z 15. a 16. století s nádobami dnem vzhůru na jižní Moravě. In: Život v archeologii stř̌edověku (Kubková, J.-Klápště, J.-Ježek, M.-Meduna, P., edd.), 639-648. Praha.

UREŠOVÁ, L., 2001: Zlatnictví. In: Sláva barokní Čechie. Stati o umění, kultuře a společnosti 17. a 18. století (Vlnas, V., ed.), 208-222. Praha.

VÍCH, D., 2017: Arrowhead finds from Zítkov Castle near Choceň, Acta Militaria Mediaevalia XIII, $83-109$. 
ZÁPALKOVÁ, H., 2010: Olomoučtí zlatníci doby baroka. In: Olomoucké baroko. Výtvarná kultura let 1620-1780. Díl 2. Katalog (Jakubec, O.-Peroutka, M., edd.), 475-483. Olomouc.

- 2017: Kalichy, eucharistické pyxidy a ciboria. In: V oplatce jsi všecek tajně. Eucharistie v náboženské a vizuální kultuře českých zemí do roku 1620 (Mudra, A., ed.), 201-212. Praha.

\section{Zusammenfassung}

\section{Ein ungewöhnlicher Depotfund kirchlicher Provenienz von Burg Zítkov bei Choceň}

Am Westrand der Stadt Choceň stand eine heute Zítkov genannte Burg (Abb. 1). Die Burg pflegt man mit der im Jahr 1388 erwähnten Burg Nový Hrad zu identifizieren.

Im Frühjahr 2014 wurde den Archäologen des Regionalmuseums in Vysoké Mýto ein beschädigtes neuzeitliches Keramikgefäß gezeigt, dass bei einer privat durchgeführten Detektorsuche in der Kernburg entdeckt wurde (Abb. 2). Das Gefäß (Abb. 3) enthielt den Torso eines zerschnittenen silbernen und stellenweise vergoldeten Kelches (Abb. 4-6), der vom Finder als rezenter Abfall angesehen wurde. Nachdem man die Bedeutung des Fundes und die Tatsache erkannt hatte, dass es sich um einen Fund von einer archäologischen Fundstelle handelt, wurde der Komplex direkt den Sammlungen des Regionalmuseums in Vysoké Mýto übergeben (Untersammlung Archäologie, Inv.-Nr. 7551-7552). Laut Information des Finders und nach einer Überprüfung der Situation am Fundort lag der Komplex in einer Tiefe von ungefähr $30 \mathrm{~cm}$ unter den Wurzeln einer Buche in einem von einem von einer Waldhumusschicht bedeckten hellgrau-braunen Sandboden im Hang in einer üblicherweise als Souterrain des nördlichen Palasbaus interpretierten Senke.

Der Kelch stellt den wichtigsten Bestandteil des für Gottesdienste erforderlichen liturgischen Mobiliars dar und machte im Laufe des Mittelalters und der Neuzeit eine Entwicklung durch. Die auf Burg Zítkov gefundenen Bruchstücke zeichnen sich durch eine sehr einfache Morphologie und durch das Fehlen einer komplizierteren Verzierung aus. Von dem Kelch ist bloß ein Teil des Fußes (Pes), der am Rand durch ein einfaches Perlschnurdekor verziert ist, und ein Teil des Schaftes (Stipes) mit Knauf (Nodus) erhalten geblieben. Dieser ist einfach ziseliert und mit einem einfach ausgehämmerten Ornament verziert. Der unausgeprägte Charakter der erhaltenen Bruchstücke macht keine eindeutige Datierung möglich, wir können sie jedoch grob in die Zeit des Spätmittelalters und der frühen Neuzeit legen (15.-16. Jahrhundert). Das Gefäß entspricht seiner Ausführung nach der Keramikproduktion, wie wir sie im fortgeschrittenen 16. Jahrhundert bis in den Verlauf des 17. Jahrhunderts kennen.

Funde von liturgischen Geräten begegnen wir in archäologischen Quellen auf dem Gebiet der Tschechischen Republik selten, und zwar sowohl in Bestattungs- als auch in Siedlungskontexten. Die Ursachen einiger ungewöhnlicher Funde können anhand von schriftlichen Quellen verdeutlicht werden, und zwar vor allem durch erhalten gebliebene Strafprotokolle (Verhörprotokolle), in denen von den Gründen und Abläufen von Diebstählen in Stadt- und Dorfkirchen die Rede ist. Diebstähle von Kirchenausstattungen tauchen darin relativ selten auf, und zwar aus zweierlei Gründen. Einerseits wegen der für Kirchenraub verhängten strengen Strafen, andererseits weil man auf diese Weise erworbenes Edelmetall nur schwierig zu Geld machen konnte. Deshalb hat man entsprechendes Diebesgut direkt nach Erbeutung in kleine Teile zerschnitten und als gefährliches potenzielles Beweismaterial an sicheren und gut identifizierbaren Orten versteckt, damit man es anschließend zu einem Hehler befördern konnte, der häufig jüdischer Herkunft war.

Die Aussage von schriftlichen Quellen über ähnliche Ereignisse und das Zeugnis des Fundes selbst sowie der Fundumstände erlauben es, die Fundsituation von Zítkov als Beleg für einen 
offenbar in einer der umliegenden Kirchen begangenen Diebstahl zu interpretieren, woraufhin man das liturgische Gerät in kleine Stücke zerschnitten und ein Teil des Diebesgutes (vom Kelch ist ungefähr ein Drittel bis die Hälfte erhalten geblieben) an einem morphologisch auffälligen Ort der untergegangenen Burg versteckt hat. Der Grund, warum das Diebesgut dann nicht mehr gehoben wurde, ist unbekannt.

Mgr. Martin Čechura, Západočeské muzeum v Plzni, Kopeckého sady 2, 30100 Plzeň, Česká republika, mcechura@zcm.cz

PhDr. David Vích, Regionální muzeum ve Vysokém Mýtě, Šemberova 125, 56601 Vysoké Mýto, Česká republika,dvich@centrum.cz 
